\title{
Determinants of Real Earning Management: A Study in Public Listed Companies in Pakistan Stock Exchange
}

\author{
Saeed Siyal $^{*} \quad$ Waqas Ahmed $^{\dagger} \quad$ Muhammad Musa Kaleem $^{\ddagger} \quad$ Lulu Wang $\S$
}

\begin{abstract}
The organizations consider earning as a key factor for their long term survival. If the organizations are not properly managed their organizations then their long term survival and competitive advantage could not be achieved. The current research studied the moderating impact of audit committee independence in the relationship between structure of board (size, independence, and duality of CEO) and real earnings management (REM) in the listed companies of Pakistan. Data was gathered from 150 firms' year wise observations of the industrial and service sectors of Pakistan stock exchange from the year 2010-2019. Using the fixed effect size approach, the findings show the negative and significant effect of board size and CEO duality on REM. While, the audit committee independence moderated the relation between board structure and REM which weakens the board size impact and CEO duality on the REM determination and increases the effectiveness independence in controlling REM.
\end{abstract}

Keywords: Real earnings management, audit committee independence, board structure.

\section{Introduction}

The board structure plays an important role in maximizing organizational performance by setting strategic priorities for the company (Chouaibi, Harres, \& Brahim, 2018). Moreover, the board is an important mechanism of internal corporate governance (CG) to improving the quality of financial reports, and plays a vital role in reducing the agency issue, therefore the effectiveness of the board depends on the characteristics of the board of directors (Dakhlallh, Mohd Rashid, Abdullah, \& Dakhlallh, 2019).

Financial reporting is an important responsibility and a central element of a corporate structure, since financial reporting acts like a crucial means of communication among the companies and stakeholders. The aim of financial reporting is therefore to give reliable information on the financial situation and the company's performance (Barth, Landsman, \& Lang, 2008). Therefore, financial reports are often frequently deformed or even deceptive. In the meantime, earnings management is one of the reasons why financial reporting is not of a standard, so it may hamper successful decision making by a firm's investors and other stakeholders in the process (Mishra \& Malhotra, 2016).

\footnotetext{
${ }^{*}$ School of Economics and Management, Beijing University of Chemical Technology, Beijing, China.

Email: saeedsiyal@gmail.com

${ }^{+}$School of Public Affairs, University of Science and Technology of China, Hefei Anhui, China.

Email: waqasdayo@yahoo.com

‡Federal Urdu University of Arts, Science and Technology, Islamabad, Pakistan. Email: mmusa.kaleem@fuuast.edu.pk

§ Renmin University of China. Email: wanglulu1999@ruc.edu.cn
} 
Management of earnings (EM) acts as a strategic method that management uses on the basis of optimizing a company's productivity and reducing risks (Bala \& Kumai, 2015). Consequently, the manipulation of earnings is intended to conflict with the financial reporting process in order to achieve a personal advantage or for the organisation. In addition, EM manipulate by real earnings management (REM) activities, as tracking REM practices compared to accrual-based earnings management (AEM) is more difficult for auditors and supervisory bodies. Given the stringent steps that force companies to not engage in AEM practices (Chi, Lisic, \& Pevzner, 2011), companies turn to REM. Several academic studies, documents and authorized testimonials have point out that the listed businesses, especially non-financial firms, participate in EM. Such activities were due to the drawbacks of the existing CG and also due to the lack of accounting regulations. Another Jordanian study has suggested that the problem of EM has caused many Jordanian companies to collapse (Cossiga et al., 2018). Jordan ranks high among the 39 countries sampled for the ranking-based study, indicates that Jordan is among the most active countries in REM. Furthermore, Dakhlallh et al. (2019), pointed out in a modern study that the Jordanian companies manipulate earnings through real activities and discretionary accrual. As a result of that, scandals and malpractice have resulted in a substantial decline an infringement of the confidence of Jordanian investors, particularly after the conversion of five public shareholders companies to compulsory liquidation in 2017. These studies had shown a major focused on other countries but had a little attention on Pakistan. Therefore, after seeking this gap there is a need of time to conduct a research in Pakistan context.

After seeking this gap, the modern studies show that good CG may mitigate manipulation of earnings and because the board of directors is a significant mechanism for CG, in addition to the function of the audit committee as an intermediary among the external audit and board of directors to improve its oversight in the process of financial reporting. We examine whether the independence of the audit committee has a moderate impact on the relation between the board of directors and REM. Nonetheless, the current study highlights the board structure that plays a significant role in mitigating REM activities, as well as the independence of the audit committee as a moderator variable. The contribution of the current study is through: First, this paper is to investigate the impact of the board of directors structure on the limitation of REM. Secondly, following the introduction of the Pakistan Corporate Governance Code, this study is the first to explore the effect of board structure on limiting REM with the effect of audit committee independence as a moderator variable. Third, the results of this study are valuable to policymakers and regulators trying to formulate strategies for CG. The present research thus bridges the relevant gap by analyzing how the board of directors influences the REM of non-financial Pakistan firms and how the audit committee independence influences this connection. 


\section{Literature Review and Hypothesis Development}

\section{Real Earnings Management}

EM is a topic that was examined extensively in prior accounting and financial researches. Managers may exploit earnings by exercising control discretion over accounting (Beasley, 1996), or direct management by participating in real-manipulation practices, cash flow manipulation, and EM by manipulating real operations to delude certain stakeholders.

The evidence shows managers favour the REM approach compared to AEM managing (Graham, 2005). While Gunny (2010) indicated the management of real practices is much more costly to companies and their shareholders and less costly for managers. Actually, REM imposes high long-term costs on shareholders as compared with AEM. Additionally, Cohen and Zarowin (2010); Zang (2012) pointed out that REM strategies do not help the growth and competitive characteristics of firms because of their long-term impact on overproduction, income manipulation and discretionary cost reduction. Since manipulating real activities leads to adverse economic consequences, understanding how to reduce this opportunistic behaviour is a critical issue, especially after the study by Graham (2005) discovered that REM activities are a common practice. Therefore, in this paper, we employ operating cash flow, expenditures of discretionary, and costs of production to estimate a measure of overall REM, according to Roychowdhury (2006) that firms may provide a price discount to raise revenue, overproduction to report a higher gross profit margin ratio, and discretionary expenditure to reflect inflated earnings can be reduced.

\section{Board Structure and Real Earnings Management}

Empirical research has identified many of the CG mechanisms for reducing agency issues resulting from EM and has shown that REM or AEM is constrained by some of the mechanisms of CG such as structure of the board (Adams, Hermalin, \& Weisbach, 2010; Kang \& Kim, 2012).

Accounting literature puts great emphasis on the board as the management team's control mechanism. In this context, Fama \& Jensen (1983) considered the board of directors is a mechanism of governance that performs a key role of firm' monitoring. Several researchers attribute the significance to the forces the companies have made available to the board (Johnson, Daily, \& Ellstrand, 1996). In addition, Godard and Schatt (2000) claim that the efficacy of the board in carrying out its duties depends on certain mechanisms.

\section{Board Size}

The theory of the agency would suggest a major role for the board structure in reducing or mitigating the problem of agency. Board size may also play a significant function in raising the efficacy of controlling decisions on EM. Similarly, that big boards should use their time and resources to conduct supervisory functions to alleviate the agency issue, whereas small boards may fail to discover earnings management activities. As a result, 
the board has carried out several board-sized related works as an internal management effectiveness method (Beasley, 1996). Such inquiries led to contradictory conclusions.

Many authors advocate for a large board of directors, a board comprising of a large number of members demonstrates greater competency resulting from the breadth skills and know-how of their members in different fields. In accordance with this view, find that abnormal discretionary expenditures are improved as the board size increases. In addition, the findings of a study by Talbi, Omri, Guesmi, and Ftiti (2015) show a favourable correlation between the board's size and REM. Also, Kharashgah, Amran, and Ishak (2019) presented proof of 721 firm-year findings of 2001-2017 from non-financial Jordanian companies and concluded that the size of board improves REM.

Concerning the reduced size of the board, Sáenz González \& García-Meca (2014) discovers that the board size causes problems of communication and collaboration between members, leading to a reduction in the control of the top management and thus to a raise in the EM. Several studies have established that the size of the board to adversely affect EM (Patrick, Paulinus, \& Nympha, 2015; Amran, Ishak, \& Manaf, 2016). Similarly, Chouaibi et al. (2018) reported that the board's size could curb the manipulation of sales of 29 listed Tunisian companies over the period 2009-2013.

At the other side, they did not record any influence of the board size on REM activities. Likewise, Alhaddad \& Whittington (2019) failed to demonstrate a connection for the size of the board with REM in Jordanian companies for the period 2010-2014. Accordingly, the hypothesis is proposed as follows:

\section{H1: The effect of board size on REM is a significant.}

\section{Board Independence}

Most of the preceding empirical studies indicate that the board of directors must consist of independent directors (Shleifer \& Vishny, 1997). Fama (1980) and Fama \& Jensen (1983) suggest in this regard that independent members are improving the Board's efficacy as a control mechanism. However, Forker (1992) suggested that the managers would be required to demonstrate compliance with the expectations of shareholders. Based on agency theory, the board's independence mainly relates to the number of independent directors. Empirical studies findings examining the link between the REM and independence of the board were mixed. Hsu, Wen, et al. (2015) reported that the board's independence is positive and significantly impacted to REM. Likewise, suggested that the board's independence inflated the REM of 108 Jordanian public firms.

Contrary, Talbi et al. (2015) discovered a negative relevance of the board independence on discretionary expense and abnormal cash flow, whereas a positive with the abnormal cost of production. J.-L. Liu and Tsai (2015) have pointed out that strengthened independence of the board leads to greater suppression of REM proxies in Taiwanese companies. Furthermore, Chouaibi et al. (2018) confirmd that board independence limits the sales manipulation of 29 companies listed in Tunisia over the period from 2009 to 2013. In recent research by Rajeevan \& Ajward (2019) for the period 2015 to 2017, it was discovered that board independence contributes to a reduction in real practices in EM. 
Sun, Lan, \& Liu (2014) have reported that there is no impact of the board independence on REM. In the same vein, Swai (2016) reported an insignificant relationship for the influence of independence of the board on REM proxies in a study of 44 non-financial companies listed in East African security markets from 2004-2013. Similarly, in non-financial Jordanian companies, Kharashgah et al. (2019) failed to find an effect of board independence on the REM. Based on explaining above, the hypothesis was as a following:

\section{H2: The effect of board independence on REM is a significant.}

\section{CEO Duality}

The duality was the topic of much controversy throughout the literature, especially between the institutional theory and agency theory. Proponents of the theory of the agency advocate for a separation of control roles and decisions, they propose that splitting the two positions allows the business to have two employees with different skills (Cornett, Marcus, \& Tehranian, 2008). Conversely, those who promote institutional theory embrace duality. The dual CEO and Chairman role enable the company's management to be united based on consistency and continuity. The stability, therefore, increases the board's functioning (Godard \& Schatt, 2000). Existing research have published conflicting results about the duality of CEOs and the relationship of REM. Ge and Kim (2014) pointed out a significant and positively of CEO-duality on REM. In addition, Kharashgah et al. (2019) concluded that the duality of CEOs improves REM in 721 firm-year findings in Jordanian non-financial companies from 2001 to 2017.

Contrary, J. Liu (2012) has reported that a higher percentage of CEO duality lowers activities in earnings management. Further, the results reported that CEO duality has an insignificant connection with REM, likewise, Garven (2015) did not document any association. Similarly, Chouaibi et al. (2018) failed to find an influence of CEO duality on REM of 29 Tunisian-listed companies. Therefore, we suggested the hypothesis as below:

H3: The effect of CEO duality on REM is a significant.

\section{The Moderating Effect of Independence of the Audit Committee}

In recent decades significant reforms have been implemented to boost the audit committees' performance. Reform to improve the transparency of audit committee emphasizes on independence of audit committee's members. Since the audit committee is one of a sub-committee of the board of directors containing non-executive members who are related to the audit and internal control matters as well as with preparing financial reports (Spira, 1998), the audit committee acts as an intermediary among the external and internal auditors along with the board of directors to the supervisory role for the process of the financial reporting.

Additionally, the audit committee must be independent of the administration to be able to exercise effective oversight. Accordingly, prior empirical evidence indicates that independence of members related to audit committee will help balance the conflicting 
opinions of external auditors and management in delivering high-quality financial information. In Jordanian case, two-thirds of the members of the audit committee must be independent and non-executive, as set out in the CGC of 2009. As just that, audit committees are formed by boards of directors to supervise the financial activities of management and serve as a link between external auditors and management (Van den Berghe \& Levrau, 2004).

The audit committee's position represents the concept of theory of agency and the require to restrict the ability of managers to receive special benefits from the business (Badolato, Donelson, \& Ege, 2014). The independent audit committee should also monitor management effectively and minimize its opportunistic behaviour. Khalil and Ozkan (2016) further claimed that the influence of board structure on EM activities attach on the composition of the audit committee. While Klein (2002) shows that companies with boards and audit committees with fewer independent directors would have more unnatural entitlements. Besides, they indicated that substantially EM is lower after the firms meet the independence criteria, this implies that the board of directors independence and the audit committee independence have a negative and significant association with EM. Furthermore, Abata and Migiro (2016) provided empirical proof from Nigeria that the board of directors' independence and independent audit committee are insignificantly associate with EM.

Similarly, Davidson, Goodwin-Stewart, \& Kent's (2005) findings indicate that power over earnings is lower whenever the bulk is independence members for the audit committee and board of directors. In addition, after the mandatory implementation of IFRS, the audit committee and board's independence perform a key role in curbing EM (Marra, Mazzola, \& Prencipe, 2011). As well, Kapoor and Goel (2017) claimed that the independence of the audit committee had a major negative influence on EM. Consequently, we may conclude that the board members' independence and audit committee members' independence are successful in enhancing the quality of earnings by reducing the EM practice. On the other hand, they pointed out that the board performs a restricted role in the case of REM, while no influence of audit committee to control over managers' behaviors. In addition, Talbi et al. (2015) showed that, at traditional rates, the impact of audit committee independence on the overall REM proxy is negligible. Whereas, points out to an insignificant effect of the audit committee independence and EM' indicator. In the same vein, in a recent study during the period 2015 to 2017, the audit committee's independence an insignificant effect on $\mathrm{REM}^{\prime}$ proxies. Thus, we present the following hypothesis: H4: The effect of board structure on REM when the audit committee independence is a significant.

\section{Data and Methodology}

There are two types of research approaches, one is quantitative and other is qualitative. The current study had applied the quantitative research approach and used longitudinal research design. The secondary data was collected in the current study. Data combination of current study comprises of the public firms listed on the Pakistan Stock Exchange (PSX) 
over the period 2010 to 2019 for ten consecutive years. The present study was carried out primarily in the industrial and service sector listed in PSX. The robustness of the analysis and to understand the roles of corporate governance frameworks in relieving REM activities and enhancing the transparency and reliability of recorded earnings. The current study was conducted on the 150 listed firms. The current research data set includes financial and non-financial information for the selected companies. Financial information was obtained from the available data released from the Data Stream database for REM. As regards, non-financial information for board independence and audit committee independence were collected manually from the available annual reports published on the PSX website.

\section{Variables Measurement}

\section{Real Earnings Management Measurement}

We use Cohen and Zarowin (2010); Roychowdhury (2006) models to measure a total estimate based on operating cash flows of abnormal (CFO), production costs of abnormal (PROD) and discretionary expense of abnormal (DISEXP) to calculate the manipulation of real operations.

\section{Cash Flow from Operations}

This approach can enhance the current period's earnings and sales volume, dissembling a positive margin. In addition, saving price discounts and credit terms will further reduce the permissive current-period cash flow producing in operating cash flow of abnormal. Operating cash flows of abnormal value will decrease owing to sales manipulation so that actual earnings management will be poor if the cash flows from abnormal value operations are high. The follows of the estimates:

$$
C F O_{i t} A_{i, t-1}=a 0+a 1\left(1 / A_{i, t-1}\right)+a 2\left(S_{i t} / A_{i, t-1}\right)+a 3\left(\Delta S_{i t} / A_{i, t-1}\right)+\epsilon_{i t}
$$

Where $C F O_{i t}$ Cash flow operation, $A_{i, t-1}$ total assets of firm i at the end of period $\mathrm{t}, S_{i t}$ is the Sales of firm i during period $\mathrm{t}, \Delta S_{i t}$ change of sales $\left(\Delta S_{i t}=S_{i t}-S_{i t-1}\right)$. Abnormal CFO obtained residual value from equation (1).

\section{Discretionary Expenses}

Corporations may reduce expenses of discretionary such as general management, expenditure related to development and research, advertisement, and sales. This scenario can improve current period earnings and cash flow with the risk of reducing future period cash flows. Reduction in discretionary load would reduce discretionary expenses with 
an abnormal value, thus, if the amount with abnormal discretionary expenses was high, REM would reduction. Hence, we estimate discretionary expenses are following:

$$
D I S X_{i t} / A_{i, t-1}=a 0+a 1\left(1 / A_{i, t-1}\right)+a 2\left(S_{i t} / A_{i, t-1}+\epsilon_{i t}\right.
$$

Where $D I S X$ is firm' discretionary expenditure i in period $\mathrm{t}$, (amount of sales and general expense, the expense of advertising and expense of development and research), $S_{i t}$ is previously sales. Discretionary expenses of abnormal acquired residual value from equation (2).

\section{Production Cost}

Companies should generate more good units than necessary in order to increase earnings so that operations would reduce the cost of the products sold. Due to the overproduced that minimize the sold goods' cost is induced by the perversion of the costs of fixed overhead by a greater number of units. Furthermore, if management manipulates earnings through overproduction, it may result in an abnormally rise production costs' level. Therefore, the production cost is the change in inventory and the number of goods sold (Roychowdhury, 2006).

$$
P R O D_{i t}=C O G S_{i t}+\Delta I N V_{i t}
$$

Where $C O G S_{i t}$ are goods sold cost of the firm i in period t, $\Delta I N V_{i t}$ is the inventory change of firm $\mathrm{i}$ in period $\mathrm{t}$. We estimate the following regression model to calculate production costs of abnormal $\left(P R O D_{i t}\right)$ :

$$
\begin{gathered}
P R O D_{i t} / A_{i, t-1}=a 0+a 1\left(1 / A_{i, t-1}\right)+a 2\left(S_{i t} / A_{i, t-1}\right)+a 3\left(\Delta S_{i t} / A_{i, t-1}\right)+ \\
a 4\left(\Delta S_{i, t-1} / A_{i, t-1}\right)+\epsilon_{i t}
\end{gathered}
$$

Where $P R O D_{i t}$ Production cost, $\Delta S_{i, t-1}$ sales' changing. Abnormal cost of production acquired residual value from equation (4). REM's final estimate is abnormal costs of production, calculated by equation's residual value (4). A large $P R O D_{i t}$ value, shows high REM due to overproduction contributes to a higher value of elevated production costs.

\section{Total Real Earnings Management}

To estimate the REM percentage. Residual values of equation (1) and (2) are combined by $(-1)$ such that the real cash flow from operations and real expenses of discretionary are smaller than the cash flow operations and the expected expenses of discretionary when managing expenses of discretionary and/or sales. This measure is the sum of all three proxies residual operations to transform changes in different processes into one unit (Chi 
et al., 2011; Cohen \& Zarowin, 2010). The bigger the result, the higher the degree of manipulation of real activities exploited by a corporation. We follow the equation to calculate REM:

$$
R E M_{i t}=-\left(A B C F O_{i t}\right)-\left(A B D I S X_{i t}\right)+\left(A B P R O D_{i t}\right)
$$

\section{Board Structure Measurement}

We research the effect of the board structure on REM and utilize the size of the board, independence and CEO duality to estimate the structure of the board. Therefore, size of the board is total directors of the board in the firm during the accounting year, while the independence of the board is a non-executive directors' proportion, the duality of CEO measured as a duma variable (equals 1 if the role of chairman and CEO are combined, and 0 otherwise).

\section{Audit Committee Independence Measurement}

We plan to test the moderating impact of audit committee independence on the association between board structure and REM, thus, we employ the proportion of non-executive members of the Audit Committee as a measure of independence.

\section{Regression Model}

To test our hypotheses, we perform balanced panel data. Balanced panel data are more much better to provide factors difficult to estimate in the study of pure time-series or pure cross-sectional. For independent and moderator variable, we use lagged values to monitor possible endogeneity between independent directors and the exploitation of real activities. Ultimately, the Fixed Effect techniques method was used to analyze the data to determine the link among the selected components and REM. The model used in this particular study is as follows, based on the above description:

$$
\begin{array}{r}
R E M_{i t}=a 0+a 1 A Z_{i t}+a 2 A C I_{i t}+a 3 C E O_{i t}+a 4 A z * A C I_{i t}+a 5 A C I * A C I_{i t}+ \\
a 6 C E O * A C I_{i t}+\epsilon_{i t}
\end{array}
$$




\section{Empirical Results and Discussions}

\section{Descriptive Statistics}

\begin{tabular}{|c|c|c|c|c|c|c|c|}
\hline Variable & Mean & Maximum & Minimum & Std. Dev & Skewness & Kurtosis & Probability \\
\hline \multicolumn{8}{|c|}{ Real Earnings Management Variables } \\
\hline REM & 2.20E-12 & 3.530315 & -3.909329 & 0.46842 & 2.199423 & 26.16245 & 0.000000 \\
\hline ABCFO & $-9.67 \mathrm{E}-12$ & 0.835218 & -0.688776 & 0.118844 & 0.547187 & 9.203609 & 0.000000 \\
\hline ABDISX & $5.49 \mathrm{E}-13$ & 1.122650 & -0.178923 & 0.097013 & 3.798912 & 29.82707 & 0.000000 \\
\hline ABPROD & $-2.20 \mathrm{E}-12$ & 3.673516 & -3.612941 & 0.40245 & 4.123519 & 45.33200 & 0.000000 \\
\hline \multicolumn{8}{|c|}{ Board Structure Variables } \\
\hline $\mathrm{BZ}$ & 7.923077 & 13.00000 & 3.000000 & 2.344062 & 0.492513 & 2.507238 & 0.000000 \\
\hline $\mathrm{BI}$ & 0.405986 & 0.909090 & 0.000000 & 0.230841 & -0.016296 & 2.230500 & 0.000013 \\
\hline CEO & 0.191209 & 1.000000 & 0.000000 & 0.393469 & 1.570445 & 3.466298 & 0.000000 \\
\hline \multicolumn{8}{|c|}{ Moderating Variable } \\
\hline $\mathrm{ACI}$ & 0.793387 & 1.000000 & 0.000000 & 0.349811 & -1.433374 & 3.491573 & 0.000000 \\
\hline
\end{tabular}

Table 1 provides descriptive statistics for all chosen variables to be used in the current analysis. REM in Pakistan ranges from -3.91 to 3.53, while the mean is 2.2E-12, meaning Pakistan industrial and service firms are widely practiced REM, this results in confirming Enomoto's et al. (2015) findings that Pakistan is among the countries with the most active REM practices. The abnormal operating cash flow from ranges from -0.69 to 0.84 .

In addition, the abnormal discretionary expenditure ranges from -0.18 to 1.12 , while the abnormal cost of production ranges from -3.61 to 3.67 , which is a high percentage, meaning that Pakistan industrial and service firms depend on the abnormal cost of production to manipulate earnings.

For board structure variables, Table 1 discovered that the BZ mean is 8.09 , while the BI mean is 0.41 , indicating that just under half of the Pakistan companies are largely consistent with recommendations of ASE which are one-third members at least should be independence. The mean CEO duality is 0.19 , indicating that about $81 \%$ of Pakistan companies obey the duality-related ASE recommendations. Table 1 also indicates that the mean of the moderate variable $(\mathrm{ACI})$ is 0.79 , indicating that most Pakistan companies comply with ASE recommendations related to audit committee which are two-thirds of them to be independent.

\section{Stability of the Model}

During the analytical times, the stability of the parameters is investigated using the $\mathrm{Cu}$ mulative sum of recursive residuals (CUSUM) established by Brown, Durbin, and Evans (1975). Such tests are significant since calculated coefficients can differ in the dates of the time series if a model is described as a mis-specification. In addition, the graphical analysis of CUSUM was shown in Figure 1. Straight lines display major boundaries from the graph at a modest 5 per cent point. The results demonstrate the consistency of the parameters as the test plot is within acceptable limits at a rational 5 per cent point, i.e. the 
regression coefficients are constant over time (Shahbaz, Hooi Lean, \& Kalim, 2013).

\section{Figure 1}

CUSUM test

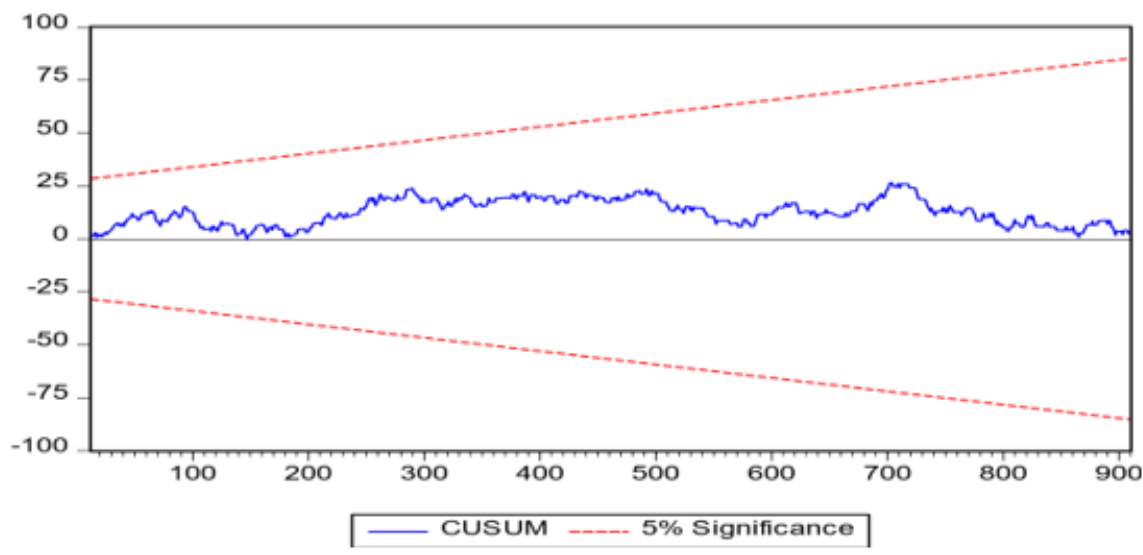

\section{Regression Analysis}

The model regression results are reported in Table 2. Columns display the results each of the proxy (ABCFP, ABDIS, ABPROD and REM_All) respectively serve as the dependent variable. The findings are reported from the regression analyzes. In all model variants, the board size has a negative and significant coefficient, suggesting that high-size boards in Pakistan are curb of participating in REM, the reason being that large boards succeed in finding and reducing REM practices in companies. That result is consistent with Amran et al. (2016); Chouaibi et al. (2018) and is not in line with Talbi et al. (2015); Kharashgah et al. (2019).

Table 2

Summary of Fixed Effect Model

\begin{tabular}{lcccccccc}
\hline & \multicolumn{2}{l}{ ABCFO } & \multicolumn{2}{l}{ ABDISX } & \multicolumn{2}{l}{ ABPROD } & \multicolumn{2}{l}{ REM_ALL } \\
Variable & Coeff & t-Statis & Coeff & t-Statis & Coeff & t-Statis & Coeff & t-Statis \\
\hline BZ & -0.013 & $-5.490^{*}$ & -0.001 & $-6.750^{*}$ & -0.047 & $-8.011^{*}$ & -0.028 & $-3.239^{*}$ \\
BI & 0.133 & $2.820^{*}$ & 0.004 & $2.879^{*}$ & 0.237 & $3.345^{*}$ & 0.272 & $2.970^{*}$ \\
CEO & 0.102 & $5.081^{*}$ & 0.029 & $3.275^{*}$ & -0.275 & $-4.331^{*}$ & -0.118 & $-2.730^{*}$ \\
ACI BZ & 0.019 & $8.016^{*}$ & 0.002 & $2.250^{* *}$ & 0.009 & $2.604^{*}$ & 0.156 & $16.196^{*}$ \\
ACI*BI & -0.154 & $-3.058^{*}$ & -0.017 & -0.895 & -0.247 & $-3.274^{*}$ & -0.251 & $-2.584^{* *}$ \\
ACI $^{*}$ CEO & -0.078 & $-3.239^{*}$ & -0.03 & $-2.952^{*}$ & 0.064 & 1.645 & 0.125 & $2.478^{* *}$ \\
Cons & -0.038 & $-3.621^{*}$ & 0.00 & -0.042 & -0.044 & $-2.832^{*}$ & -0.053 & $-2.603^{*}$ \\
\hline R-squared & 0.637388 & 0.599829 & 0.478995 & 0.499459 \\
Adj R-sq & 0.637041 & 0.599802 & 0.478841 & 0.499376 \\
P(F-stat) & 0.000000 & 0.000000 & 0.000000 & 0.000000 \\
Durbin- Watson & 1.677065 & 1.609442 & 1.54863 & 1.583892 \\
\hline Nite
\end{tabular}

Notes: ${ }^{*},{ }^{* *}$ and ${ }^{* * *}$ Indicates the dismissal of the null hypothesis at the rates of $1 \%$ and $5 \%$, and $10 \%$ level.

As shown in Table 2, the independence of the board has a positive and significant 
coefficient in all model variants which means that independent boards are more likely to participate in REM in Pakistan. That result is in line with Hsu et al. (2015) and inconsistent with (Talbi et al., 2015; Kharashgah et al., 2019). Reason for the positive relationship is that independent directors may be insufficiently independent and the Pakistan demand for independent directors may also be immature. Additionally, the directors can lack the complexity of the accounting required to detect REM. This results in a situation that is not in line with the theory of agency, which implies that external board members will minimize the EM activities and strengthen the CG structure.

Furthermore, the duality of CEO reveals a negative and significant relationship with ABPROD and REM_ALL, whereas with ABCFO and ABDISXP have a positive impact. The finding supports the J. Liu (2012), which reported that duality lowers REM activities and is not compatible with Kharashgah et al. (2019). The negative result shows that CEO duality is the most important board function element that determines REM. This finding in the Paksitan context implies that non-separation between $\mathrm{CEO} /$ chairman roles tends to eliminate or mitigate ABPROD and REM_ALL. While this finding implies that duality in the CEOs and Chairmen's roles have a positive impact on enhancing ABCFO and ABDISXP practices in Pakistan listed firms. Based on the findings of Table 2 regarding the moderator variable, we integrate independence of the audit committee into the board structure variables in the study equation to check the moderating impact of independence of the audit committee on the relationship between board structure and REM. The result of Table 2 shows that the coefficient for $\mathrm{ACI}^{*} \mathrm{BZ}$ is positive and implies that the independence of the audit committee weakens the influence of board size in order to curb all REM proxy's practices in Pakistan companies. As shown in table 2, the coefficient for ACI*BI is significantly negative and indicates that the independence of the audit committee increases the effect of board independence to curb all REM proxies, except the coefficient for ABDISX being insignificant, which implies no moderate impact of audit committee independence on the relationship between board structure and discretionary expenses management. Furthermore, the coefficient for ACI*CEO for REM_ALL is positively significant and implies that the audit committee independence enhances the effect of CEO duality to practiced of REM, while $\mathrm{ACI}^{*} \mathrm{CEO}$ coefficient for ABDISX and ABCFO is negatively significant and implies that audit committee independence increases the effect of CEO duality to curb of discretionary expenses and cash flow from operations activities, moreover, the ABPROD coefficient is insignificant, which indicate no moderate effect of audit committee independence on the relationship between CEO duality and manipulation of production cost.

\section{Conclusion}

The current paper examined the influence of board structure on REM and moderator effect of the audit committee independence on their link. There are three forms of REM under consideration. The board size, board independence and CEO duality are tested for board structure variables. Using panel data from public companies in Pakistan for the period 2009-2018, the empirical findings show that the board structure affects the de- 
cisions of companies to manipulate reported earnings. All REM proxies are limited by the board size. In contrast, board independence exaggerates the incidence of all REM proxies, although CEO duality only exaggerates CFO and DISX but restricts PROD and REM_ALL. With regard to the moderate variable, it was found that the independence of the audit committee weakens the influence of the board size to curb all REM proxies and that the independence of the audit committee enhances the effect of the independence of the board to curb all REM proxies, except DISX. Meanwhile, it was found that the independence of the audit committee enhances the impact of CEO duality on curbing DISX and CFO, while the independence of the audit committee enhances CEO duality to the practice of REM_ALL and no moderate effect of independence of the audit committee on the relation between CEO duality and PROD. In short, the results from this study show that the moderate impact of independence of the audit committee decreases the influence of the board structure on REM determination.

Our findings offer valuable information for policymakers and regulators. Contrary to the guidelines of the 2009 JCGC, the findings of this study indicate that independent directors worsen rather than decrease the prevalence of opportunism. Whereas the merge of the audit committee's independence with the board's independence leads to a limitation of opportunistic EM practices. Policymakers do need also to consider the institutional characteristics setting before introducing further CG reforms. Probably the proportion of independent directors is too soft to control the board, their expertise being insufficient or doubtful in terms of independence. Pakistan results can also extend to other developing countries. Concerning board size, government and regulators must concentrate on this mechanism to reduce REM activities and allow businesses to increase their company's number of directors. CEO duplication is seen as increasing PROD and REM_ALL and reducing of CFO and DISX activities, which contradicts JCGC's 2009 guidelines on separation or duality of CEO.

The current study contributed to the literature by providing evidence of the moderating effect of the audit committee independence on the relationship between the board structure and REM proxies in the Pakistan environment. Eventually, for future studies, consideration must be taken the developed and developing countries to examine this relationship in order to explain the findings from a different viewpoint. Furthermore, further studies are required to examine the relationship between other board structure mechanisms (such as education, remunerations, meetings, and gender). In addition, researchers may also use manipulation of accrual-based to estimate different proxy of earnings management. 


\section{References}

Abata, M. A., \& Migiro, S. O. (2016). Corporate governance and management of earnings: empirical evidence from selected Nigerian-listed companies. Investment Management and Financial Innovations, 13(2), 189-205.

Adams, R., Hermalin, B., \& Weisbach, M. (2010). The role of boards of directors a conceptual governance: Corporate framework and survey. Jornal of Economic Literature, 48(1), 58-107.

Amran, N. A., Ishak, R., \& Manaf, K. (2016). The influence of real earnings on Malaysian corporate board structure. The Social Sciences, 11(30), 7258-7262.

Badolato, P. G., Donelson, D. C., \& Ege, M. (2014). Audit committee financial expertise and earnings management: The role of status. Journal of Accounting and Economics, 58(2-3), 208-230.

Bala, H., \& Kumai, G. (2015). Audit committee characteristics and earnings quality of listed food and beverages firms in Nigeria. International Journal of Accounting, Auditing and Taxation, 2(8), 216-227.

Barth, M. E., Landsman, W. R., \& Lang, M. H. (2008). International accounting standards and accounting quality. Journal of Accounting Research, 46(3), 467-498.

Beasley, M. S. (1996). An empirical analysis of the relation between the board of director composition and financial statement fraud. Accounting Review, 443-465.

Brown, R. L., Durbin, J., \& Evans, J. M. (1975). Techniques for testing the constancy of regression relationships over time. Journal of the Royal Statistical Society: Series $B$ (Methodological), 37(2), 149-163.

Chi, W., Lisic, L. L., \& Pevzner, M. (2011). Is enhanced audit quality associated with greater real earnings management? Accounting Horizons, 25(2), 315-335.

Chouaibi, J., Harres, M., \& Brahim, N. B. (2018). The effect of board director's characteristics on real earnings management: Tunisian-listed firms. Journal of the Knowledge Economy, 9(3), 999-1013.

Cohen, D. A., \& Zarowin, P. (2010). Accrual-based and real earnings management activities around seasoned equity offerings. Journal of Accounting and Economics, 50(1), 2-19.

Cornett, M., Marcus, A., \& Tehranian, H. (2008). Earnings management, corporate governance, and financial performance. Journal of Financial Economics, 87(2), 357-373.

Cossiga, G. A., et al. (2018). Signals from the world of economics. the price constant and the democratic issue. International Journal of Social and Administrative Sciences, 3(1), $1-21$.

Dakhlallh, M. M., Mohd Rashid, N., Abdullah, W. A. W., \& Dakhlallh, A. (2019). The mediating effect of the managerial ownership towards the influence of the board of directors on the firm performance among Jordanian public shareholders companies. Journal of Environmental Treatment Techniques, 7(4), 760-767.

Ge, W., \& Kim, J.-B. (2014). Boards, takeover protection, and real earnings management. Review of Quantitative Finance and Accounting, 43(4), 651-682.

Godard, L., \& Schatt, A. (2000). Quelles sont les caractéristiques optimales du conseil d'administration? La Revue du Financier, 127, 36-47. 
Graham, J. (2005). Harvey and s. rajgopal (2005). the economic implications of corporate financial reporting. Journal of Accounting and Economics, 40(1-3), 3-73.

Gunny, K. A. (2010). The relation between earnings management using real activities manipulation and future performance: Evidence from meeting earnings benchmarks. Contemporary Accounting Research, 27(3), 855-888.

Hsu, M.-F., Wen, S.-Y., et al. (2015). The influence of corporate governance in chinese companies on discretionary accruals and real earnings management. Asian Economic and Financial Review, 5(3), 391-406.

Johnson, J. L., Daily, C. M., \& Ellstrand, A. E. (1996). Boards of directors: A review and research agenda. Journal of Management, 22(3), 409-438.

Kang, S.-A., \& Kim, Y.-S. (2012). Effect of corporate governance on real activity-based earnings management: Evidence from Korea. Journal of Business Economics and Management, 13(1), 29-52.

Kapoor, N., \& Goel, S. (2017). Board characteristics, firm profitability and earnings management: Evidence from India. Australian Accounting Review, 27(2), 180-194.

Khalil, M., \& Ozkan, A. (2016). Board independence, audit quality and earnings management: Evidence from Egypt. Journal of Emerging Market Finance, 15(1), 84-118.

Kharashgah, K., Amran, N., \& Ishak, R. (2019). Board of directors' structure and real earnings management: Jordanian evidence. International Journal of Academic Research in Business and Social Sciences, 9(12), 742-760.

Klein, A. (2002). Audit committee, board of director characteristics, and earnings management. Journal of Accounting and Economics, 33(3), 375-400.

Liu, J. (2012). Board monitoring, management contracting and earnings management: an evidence from ASX listed companies. International Journal of Economics and Finance, 4(12), 121-136.

Liu, J.-L., \& Tsai, C.-C. (2015). Board member characteristics and ownership structure impacts on real earnings management: Evidence from Taiwan. Accounting and Finance Research, 4(4), 84-96.

Marra, A., Mazzola, P., \& Prencipe, A. (2011). Board monitoring and earnings management pre-and post-IFRS. The International Journal of Accounting, 46(2), 205-230.

Mishra, M., \& Malhotra, A. K. (2016). Audit committee characteristics and earnings management: Evidence from India. International Journal of Accounting and Financial Reporting, 6(2), 247-273.

Patrick, E. A., Paulinus, E. C., \& Nympha, A. N. (2015). The influence of corporate governance on earnings management practices: A study of some selected quoted companies in Nigeria. American Journal of Economics, Finance and Management, 1(5), 482-493.

Roychowdhury, S. (2006). Earnings management through real activities manipulation. Journal of Accounting and Economics, 42(3), 335-370.

Shahbaz, M., Hooi Lean, H., \& Kalim, R. (2013). The impact of foreign direct investment on stock market development: Evidence from Pakistan. Economic ResearchEkonomska istraživanja, 26(1), 17-32.

Shleifer, A., \& Vishny, R. W. (1997). A survey of corporate governance. The Journal of Finance, 52(2), 737-783. 
Spira, L. (1998). An evolutionary perspective on audit committee effectiveness. Corporate Governance: An International Review, 6(1), 29-38.

Swai, J. (2016). The impact of corporate governance and firm-specific characteristics on earnings management: Evidence from East Africa. Research Journal of Finance and Accounting, 7(8), 139-156.

Talbi, D., Omri, M. A., Guesmi, K., \& Ftiti, Z. (2015). The role of board characteristics in mitigating management opportunism: The case of real earnings management. Journal of Applied Business Research (JABR), 31(2), 661-674.

Van den Berghe, L. A., \& Levrau, A. (2004). Evaluating boards of directors: what constitutes a good corporate board? Corporate Governance: An International Review, 12(4), 461-478.

Zang, A. Y. (2012). Evidence on the trade-off between real activities manipulation and accrual-based earnings management. The Accounting Review, 87(2), 675-703. 